DOI: $\underline{\text { https://doi.org/10.24867/03FA12Dronic }}$

\title{
IMPLEMENTACIJA CENTRA ZA ORGANSKU PROIZVODNJU, POLJOPRIVREDU I PRODAJU U URBANO TKIVO NOVOG SADA
}

\section{IMPLEMENTATION OF THE CENTER FOR ORGANIC PRODUCTION, AGRICULTURE AND SALE IN THE URBAN TISSUE OF NOVI SAD}

\author{
Jelena Dronić, Fakultet tehničkih nauka, Novi Sad
}

\section{Oblast - ARHITEKTURA}

Kratak sadržaj - Program rada bavi se projektovanjem centra za proizvodnju, preradu i prodaju organske hrane u Novom Sadu. Osnovna ideja predloženog projekta zasniva se na centralizovanju osnovnog programa (proizvodnja) i ređanju pratećih sadržaja (mehanizacija, sortiranje robe, prerada, pakovanje i prodaja) oko njega. Krajnji cilj predstavlja podsticanje regionalne privrede $i$ proizvodnje domaćih proizvoda koji bi se zadržali na domaćem tržištu kako bi se podigla svest lokalne zajednice o važnosti kvaliteta prehrambenih proizvoda dobijenih na prirodan način.

Ključne reči: Organska poljoprivreda, organska hrana, organska pijaca, industrija

Abstract - Program of the project deals with the design of a center for the production, processing and sale of organic food in Novi Sad. The basic idea of the conceptual solution is based on the centralization of the main program (production) and organization of accompanying contents (mechanization, sorting of goods, processing, packaging and sale) around it. The ultimate goal is to encourage the regional economy and the production of domestic products to remain on the domestic market in order to raise the awareness of the local community about the importance of the quality of food products obtained in a natural way.

Ključne reči: Organic agriculture, organic food, organic market, industry

\section{UVOD}

Poslednjih nekoliko godina, sve se više govori o uzgajanju, proizvodnji i konzumiranju organske hrane. Ustaljen konvencionalan način proizvodnje sve je više potisnut kako se u prvi plan ističe značaj i kvalitet organskih proizvoda, agrikulture i potencijal ruralnih područja. S tim u vezi, neizbežna je potreba za većim brojem industrijskih objekata koji će svojim programskim sadržajima, funkcionalnošću i formom obezbediti neometan rad objekata ove tipologije $i$ istu približiti i bolje objasniti stanovništvu, kao ključnom faktoru za dalji napredak organske poljoprivrede. Stoga, predloženi projekat za cilj ima formiranje prvog gradskog centra za organsku poljoprivredu i proizvodnju u Vojvodini.

\section{NAPOMENA:}

Ovaj rad proistekao je iz master rada čiji mentor je bio dr Marko Todorov, docent.

\section{PROGRAMSKO FUNKCIONALNA ISTRAŽIVANJA}

\subsection{Osnovni principi organske poljoprivrede}

Međunarodna federacija pokreta za organsku poljoprivredu, IFOAM, postavila je osnovne principe za razvoj organske poljoprivrede. $\mathrm{Na}$ osnovu ovih principa zasnivaju se regulative Evropske unije u ovoj oblasti kao i Zakon o organskoj proizvodnji Republike Srbije.

Načela na kojima se bazira razvoj ove grane poljoprivrede su sledeći: načelo zdravlja, načelo ekologije, načelo pravednosti, načelo nege i zaštite. Principi su sastavljeni kao etički, u cilju obezbeđenja pravilnog i uspešnog razvoja organske poljoprivrede, i kao takvi izražavaju doprinos ove grane svetu i inspiraciju za dalji napredak. Malo je poznato koje su prednosti organske poljoprivrede i proizvodnje, a propagirajući osnovne principe na kojima se zasniva, sve je veća popularnost i podizanje svesti o načinu na koji se ljudi odnose prema prirodnim resursima i oblikuju nasledstvo budućih generacija.

Ovi principi takođe utiču i na odnos prema projektovanju objekta za zadovoljenje potreba organske proizvodnje. Poštovanje načela $\mathrm{i}$ potpuno shvatanje istih u procesu projektovanja, rezultira objektom specifične tipologije koji doprinosi razvoju i važnosti ove grane privrede. Samim tim, neophodno je posvetiti pažnju organskoj poljoprivredi i u oblasti arhitekture, kako bi se razvio prepoznatljiv karakter objekata ove tipologije.

\subsection{Uslovi organske poljoprivrede}

Prvi uslov za uspešnu i dugoročnu organsku proizvodnju je promena $u$ načinu razmišljanja i stavovima proizvođača, odnosu prema prirodi i zdravlju. Nameće se i osnovni princip održivog razvoja kao uslov koji se mora ispoštovati, a to je odgovornost prema budućim generacijama.

Sledeći važan uslov za započinjanje organske proizvodnje svakako su prirodni uslovi, zdravo i plodno zemljište.

Da bi se zemljište odobrilo za proizvodnju organskih namirnica neophodno je da minimum tri godine nije tretirano hemikalijama, a dozvoljena je jedino upotreba stajskog đubriva.

Takođe, voda za navodnjavanje i vazduh područja moraju biti kvalitetni za dobijanje sertifikata o organskoj proizvodnji. Važan preduslov za uspešnu organsku proizvodnju svakako je i tržište. 


\subsection{Održivi razvoj}

Održivi razvoj predstavlja integralni ekonomski, tehnološki, socijalni i kulturni razvoj, usklađen sa potrebama zaštite i unapređenja životne sredine, koji omogućava sadašnjim i budućim generacijama zadovoljavanje njihovih potreba i poboljšanje kvaliteta života. To znači da je održivi razvoj proces promene u kom su eksploatacija resursa, orijentacija tehnološkog razvoja i usmeravanje investicija u skladu sa sadašnjim i budućim potrebama.

Brojni primeri održivog razvoja su prisutni, od zelenih tehnologija, održivog turizma, pa do organske poljoprivrede koja je možda i ključna jer kao jedna od grana privrede proizvodi ono najvažnije - hranu.

Organska poljoprivreda predstavlja zaokruženu proizvodnju, jer podrazumeva razvoj održivog razvoja ruralnih područja kao i obnavljanje i očuvanje prirodnih resursa $i$ biodiverziteta $u$ celini. Tokom procesa projektovanja važno je voditi računa o svim prethodno navedenim faktorima. Te se posebna pažnja posvetila i tokom projektovanja predloženog projektnog rešenja.

\subsection{Organska proizvodnja u Srbiji}

Organska proizvodnja je jedan od najbrže rastućih sektora, a to se može videti i na primeru Srbije u poslednjih deset godina. Zakon o organskoj proizvodnji u Srbiji usvojen je 2006. godine, a novi Zakon o organskoj proizvodnji i proizvodima usvojen je 2011. godine. Od 2006. brojna istraživanja su sprovedena i ukazuju na brz razvoj ove grane poljoprivrede, sve je više područja koja se obrađuju i tretiraju kao organska, a razlog tome je najveći izvozni potencijal države - organski proizvodi. Neophodno je naglasiti da istorijsko nasleđe, podneblje državna podrška sektoru proizvodnje čine pojedine zemlje liderima u određenoj vrsti organske proizvodnje, u vezi sa tim uviđa se ogroman napredak u primeru naše zemlje. Kao relativno nova delatnost, organska poljoprivreda zastupljena je u određenoj meri na različitim lokacijama širom Srbije.

Ruralna područja zbog bogatstva i plodnosti zemljišta dominiraju preradom i proizvodnjom organskih proizvoda, iako se u poslednje vreme sve više pokušava približiti ova delatnost gradskim područjima. U Srbiji se trenutno nalaze četiri centra za proizvodnju organske hrane, a dva su gradska - Valjevo i Leskovac. Novi Sad svojom geografskom pozicijom, veličinom i okolnim ruralnim mestima poseduje mnogo potencijala za uspešnu organsku proizvodnju, a dobrom organizacijom i korišćenjem potencijala lako može postati gradski centar proizvodnje, što bi znatno uticalo na širenje mreže ekoloških zadruga u našoj državi.

\subsection{Sadržaji objekta za proizvodnju organske hrane}

Tipologija objekta za proizvodnju, diktira potrebu za velikim brojem prostora većih razmera sa kapacitetima za smeštanje neophodne mehanizacije i mašina. U zavisnosti od vrste proizvodnje, unutar prostorne celine će se definisati organizacija sadržaja i potrebni prostori za rad. Kako je tema organske proizvodnje definisana, u daljem tekstu biće govora o prostorima isključivo potrebnim za neometano funkcionisanje ove delatnosti, njenom strukturom i organizacionim jedinicama. Sam proces proizvodnje organske hrane, od unošenja plodova $u$ objekat, njihove kontrole i sertifikacije, sortiranja i magacioniranja pa do transporta $\mathrm{u}$ pogon za preradu nameće odnos sadržajnih jedinica unutar celine. Prvi korak $\mathrm{u}$ pogonu prerade je kontrola i sertifikacija proizvoda koju vrši telo, pravno registrovano i sa svojim sertifikacionim znakom. Kontrola proizvoda ne zahteva velike razmere prostora, pa može biti predprostor sortiranju i smeštanju proizvoda u magacine i hladnjače dok ne dođe do samog procesa proizvodnje.

Sam pogon prerade zahteva veći prostor i čiste komunikacije za zaposlene, pa se svlačionice smeštaju odmah do pogona za proizvodnju. Nakon dobijanja gotovih proizvoda, isti se transportuju do prostorne jedinice za pakovanje čija razmera zavisi od kapaciteta proizvodnje i radne snage. Preciznije rečeno, prostori pakovanja zahtevaju hale veličine pogonske i direktnu vezu sa sektorom za proizvodnju. Pored neophodnih prerađivačkih pogona, potrebni su i prostori opšteg karaktera dostupni javnosti. Nakon pakovanja u ambalažu proizvodi se transportuju do izložbenog i prodajnog dela, koji je pored sanitarnog čvora i prostora za degustaciju, uglavnom jedini javni.

\subsection{Krajnji cilj}

Osnovni cilj organske poljoprivrede i proizvodnje je optimalno korišćenje prirodnih resursa, proizvodnja dovoljnih količina različitih organskih i kvalitetnih proizvoda, zadovoljenje potreba potrošača i pospešivanje ekonomskog napretka u ovom polju. $\mathrm{S}$ obzirom na to, predloženo projektno rešenje sa akcentom na implementaciju centra za organsku proizvodnju, poljoprivredu i prodaju $u$ urbano tkivo grada teži uvođenju tipologije karakteristične za ruralne predele $\mathrm{u}$ veći gradski centar.

Takođe, uvođenjem jednog ovakvog objekta u urbanu sredinu utiče se i na podizanje svesti stanovništva o važnosti organske proizvodnje i konzumiranju organske hrane. Kako se organska poljoprivreda u poslednjih deset godina tek razvija, a s obzirom na potencijale koje podneblje pruža, postojanje centra za proizvodnju u urbanoj sredini uticalo bi ne samo na poboljšanje zdravlja već i kvaliteta života jedne gradske zajednice, iz tih razloga objekat ove tipologije je neophodan. $\mathrm{Na}$ osnovu sprovedenih istraživanja objašnjenih $u$ prethodnim poglavljima rada došlo se do određenih zaključaka po pitanju programsko sadržajnih odrednica i načina za maksimalno iskorišćenje lokacijskih potencijala.

\section{PROJEKAT CENTRA ZA ORGANSKU PROIZVODNJU, POLJOPRIVREDU I PRODAJU U NOVOM SADU}

\subsection{Lokacija i kontekst}

Kada je reč o širem okruženju lokalitet se pruža duž Bulevara Evrope, pripadajući Bistrici na granici sa Detelinarom u Novom Sadu. Kao što je prikazano na ilustraciji 1, u neposrednom okruženju centra za organsku poljoprivredu, proizvodnju i prodaju nalaze se brojni sadržaji neophodni za neometan život i rad ljudi. Kao i ostali delovi Novog Sada i Bistrica je vrlo dobro 
snadbevena infrastukturom i povezana je sa ostalim delovima grada gradskim prevozom te se u blizini nalazi mnoštvo autobuskih stajališta.

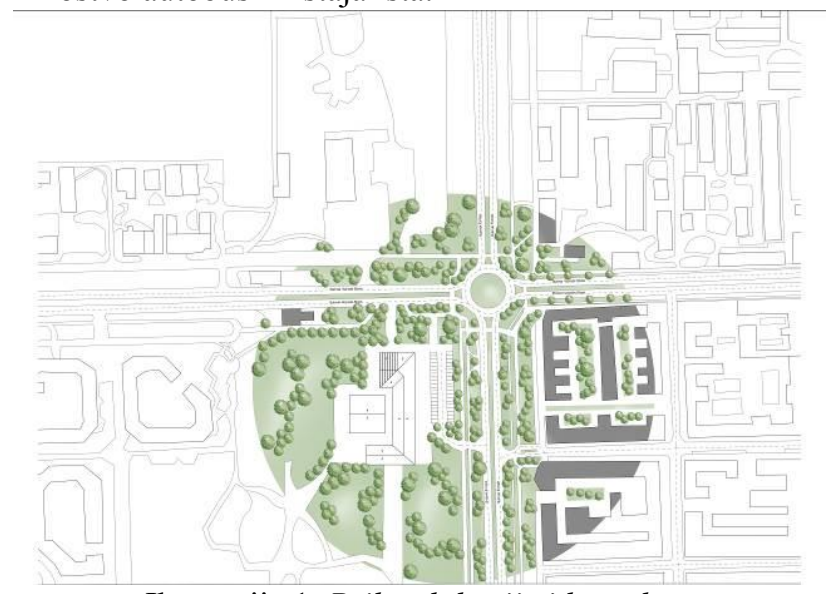

Ilustracija 1. Prikaz lokacije i konteksta

Položaj objekta na parceli određen je pre svega stranama sveta i potrebama samog programa za sunčevim zračenjem. S tim u vezi, objekat se otvara ka jugozapadnom delu parcele staklenim panelima dok se celokupna severoistočna fasada zatvara ka pešačkoj zoni. $\mathrm{Na}$ taj način pospešuje se sama proizvodnja s obzirom na količinu sunčevog zračenja koju u toku godine stakleni delovi objekta apsorbuju.

\subsection{Koncept}

Koncept projekta centra za poljoprivredu, proizvodnju i prodaju organske hrane zasniva se na centralizovanju osnovnog programa i ređanju pratećih sadržaja oko njega. Kako je objekat prvenstveno namenjen proizvodnji organske hrane bilo je neophodno obezbediti sve faktore koji tu proizvodnju pospešuju kao i prateće sadržaje koji će obezbediti pravilnu eksploataciju, kontrolu i preradu istih. Proizvodnja se smešta u dominantan staklenik pozicioniran na centralnom delu parcele, dok se sadržaji kao što su mehanizacija, sortiranje i magacioniranje robe, kontrola, pogon za proizvodnju i pakovanje samih proizvoda ređaju sa manje osunčane strane staklenika okružujući ga i pružajući maksimalan dobit funkcije.

Sa druge strane, prodajno izložbeni deo objekta pozicionira se sa lako dostupne strane parcele sa izlazom na parking u ulici Bulevar Vojvode Stepe povezujući se sa prethodno navedenim sadržajima samo jednom kontaktnom stranom. Kada je reč o formi objekta lako se može uočiti težnja da se proizvodnja poveže sa prodajnim delom objekta čineći jedinstvenu celinu, istim načinom formiranja fasadnog platna jednim delom oponašajući staklenik.



Ilustracija 1. 3d prikaz objekta i staklenika

\subsection{Programsko funkcionalna istraživanja}

Na osnovu prethodno sprovedenih istraživanja pomenutih u poglavlju 2.0 Programsko funkcionalna istraživanja, došlo se do zaključka koji sadržaji su neophodni za neometano funkcionisanje objekta.

Ti sadržaji su sledeći: portirnica sa video nadzorom, sanitarnim blokom i čajnom kuhinjom, svlačionice podeljene na sektore uz poštovanje prljavih i čistih komunikacija, prostor za odmor zaposlenih i servis za održavanje. Potom sadržaji za proizvodnju kao što su: skladište za mehanizaciju, kontrola i sertifikacija proizvoda, sortiranje i magacioniranje, hladnjače, pogon za preradu i proizvodnju, prostor za pakovanje.

Slede javni prostori: prodajno izložbeni prostor sa info pultom i sanitarnim blokom dostupnim za sve posetioce prostora.

Posebna pažnja prilikom rešavanja osnove objekta posvećena je funkcionalnom odvajanju različitih sadržajnih jedinica prostora i njihova interakcija. Tako se primeti odvajanje zona u odnosu javno-privatno tačnije, zone namenjene korisnicima i zone koje koriste zaposleni objekta, kako bi se izbegla njihova međusobna interakcija a sačuvale čiste komunikacije iz higijenskih razloga. Važno je naglasiti da se kod javnih objekata ove tipologije moraju poštovati određena pravila radi obezbeđenja sigurnosti svih korisnika prostora.

$\mathrm{S}$ tim u vezi, preduzimaju se određene mere bezbednosti kao što su: postojanje glavnog i sporednog ulaza, pozicioniranje sigurnosnog lica i video nadzora sa direktnim pogledom na ulaze kao i obezbeđenje protivpožarnih mera sigurnosti unutar samog objekta.

$\mathrm{Na}$ taj način se objekat osigurava i pruža bezbednost njegovim korisnicima.

\subsection{Konstrukcija i materijalizacija}

Konstruktivni sistem primenjen u idejnom rešenju predloženog projekta je skeletni, sa rasterom čeličnih stubova, zatim čeličnim rešetkama koje prenose opterećenje dvovodnih krovova.

Kada je reč o konstrukciji staklenika predlaže se sistem čeličnih stubova određenog rastera i čeličnih ramova koji se oslanjaju na taj raster. $\mathrm{Na}$ predloženu konstrukciju slažu se stakleni paneli koji apsorbuju od 70 do $100 \%$ sunčevog zračenja.

Što se tiče temeljenja samog staklenika, predlaže se upotreba čeličnih uklještenja nosača konstrukcije iz razloga stabilnosti. Takođe, neophodno je razmišljati o olučnom sistemu za odvodnjavanje te je predložen u vidu obešenog sistema limenog oluka četvrtastog profila. Kada je reč o formi i materijalizaciji objekta, uslovljene su samim konceptom i programskim sadržajima.

$\mathrm{S}$ tim u vezi, predlaže se upotreba betonskih površina $\mathrm{u}$ industrijskom delu objekta radi lakšeg održavanja, dok se u javnim delovima objekta (prodajno izložbeni deo) koriste nešto topliji materijali kao što su drvo i keramika. Prožimanjem dve različite materijalizacije i namene prostora teži se formiranju jedinstvene celine $\mathrm{i}$ isticanja primarne namene objekta.

To se najjasnije izražava interakcijom dve različite forme oblikovanja prostora kroz odnose čistih belih i staklenih površina. Upotrebom emajliranog stakla obezbeđuje se 
filtriranje i selekcija sunčevog zračenja, kako bi se sprečilo pregrevanje i prevelika apsorpcija štetnog zračenja a ipak zadržao željeni estetski efekat stakla.

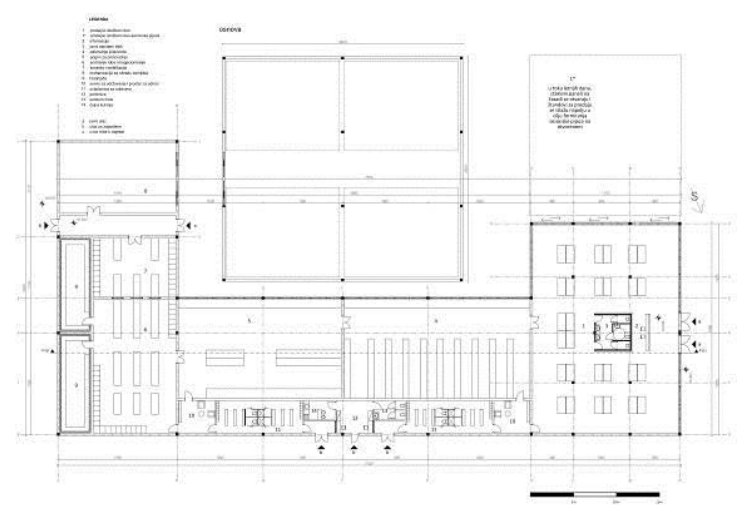

Ilustracija 2. Osnova objekta

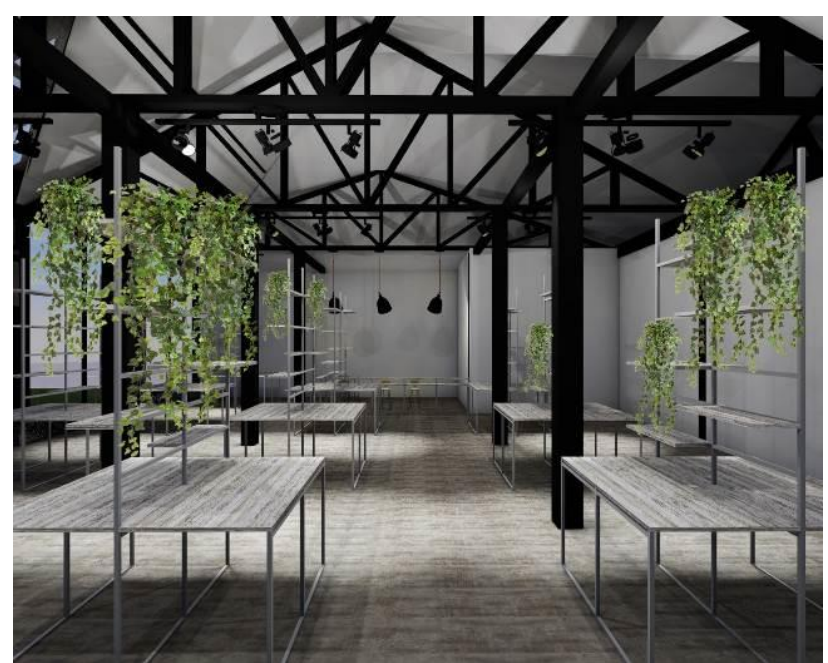

Ilustracija 3. 3d prikaz enterijera prodajnog dela

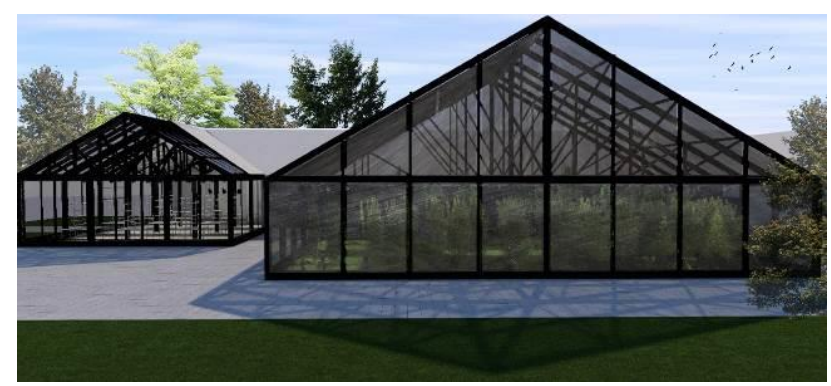

Ilustracija 4. $3 d$ prikaz objekta

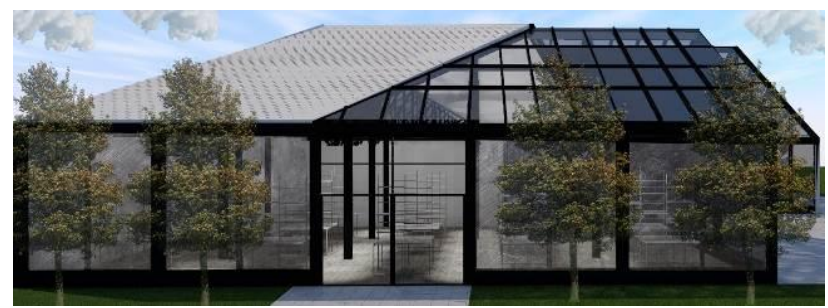

Ilustracija 5. $3 d$ prikaz objekta

\section{ZAKLJUČAK}

Idejnim rešenjem projekta na temu Implementacija centra za organsku proizvodnju, poljoprivredu $i$ prodaju $u$ urbano tkivo Novog Sada, teži se formiranju objekta tipologije koja je samom gradskom centru nedovoljno poznata, u cilju približavanja i objašnjenja iste. $\mathrm{S}$ tim $\mathrm{u}$ vezi, program rada projekta centra za poljoprivredu, proizvodnju i prodaju organske hrane predstavlja istraživački rad specifične tipologije, kojoj je potrebno pristupiti uz mnoštvo analiza programske strukture i funkcionalnih celina koje ga čine.

Koristeći prethodna iskustva stečena projektovanjem, studijskom analizom tipologije i detaljnim razvojem koncepta, pokušano je da se odgovori na najbolji mogući način zadatom programu.

Predloženo projektno rešenje proisteklo je iz konteksta, lokacije, principa organske proizvodnje, kao i svih uticajnih činioca (konstrukcija, estetika, materijalizacija i drugi), koji su bili parametri za dalje definisanje i rešavanje problema.

Osnovna ideja i cilj predloženog projekta jeste da se podstakne regionalna privreda i proizvodnja domaćih proizvoda koji bi se zadržali na domaćem tržištu u cilju povećanja svesti lokalnih zajednica o važnosti kvaliteta prehrambenih proizvoda dobijenih na prirodni način.

\section{LITERATURA}

[1] Snežana Oljača, Organska poljoprivredna proizvodnja, Univerzitet u Beogradu, Beograd, 2012.

[2] Dušan Kovačević, Zaštita životne sredine u ratarstvu $i$ povrtarstvu, Univerzitet u Beogradu, Beograd, 2011.

[3] Društvo za zaštitu bilja Srbije, Pesticidi u poljoprivredi i šumarstvu u Srbiji, 17. Izdanje, 2010. [4] Slavica Kostić Nikolić, Ekonomika poljoprivrede, stručni rad, Beograd, 2011.

[5] Prva međunarodna konferencija zdrave, ekološke i organske proizvodnje hrane (grupa autora), BioPlanet healthy, green and organic options, Zlatibor, 2010.

[6] Grupa autora, Zakon o organskoj proizvodnji

Republike Srbije, Službeni glasnik, Beograd, 2010.

[7] http://www.pks.rs/organicproductioninserbia.pdf (datum pristupa 18.10.2018.)

[8] https://www.tehnologijahrane.com/knjiga/organakaprerada (datum pristupa 18.10.2018.)

[9] https://www.tehnologijahrane.com/iznovina/organska-proizvodnja-u-funkciji-odrzivograzvoja-srbije (datum pristupa 20.10.2018.)

\section{Kratka biografija:}

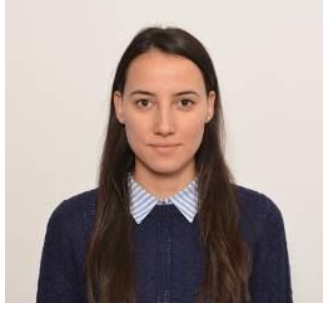

Jelena Dronić rođena je u Sremskoj Mitrovici 1994. godine. Osnovne akademske studije završila je 2017. god na Fakultetu tehničnih nauka u Novom Sadu, na kom brani i Master rad 2018. godine iz studijskog programa Arhitektura, oblast Dizajn enterijera. 